\title{
Inhibitory concentrations of gambier (Uncaria gambir Roxb.) catechins extract against Streptococcus mutans
}

\author{
Jesieca Inmawaty*, Indrati*, Mieke Hemiawati Satari* \\ *Department of Oral Biology Faculty of Dentistry Universitas Padjadjaran
}

\begin{abstract}
Introduction: Catechin which extracted from gambir (Uncaria gambir Roxb) is a major component of polyphenol compounds. The catechins compound acts as an antibacterial. The study was to analyze the inhibitory concentration gambir catechin extract against Streptococcus mutans as the bacteria that play a role in the formation of dental caries. Methods: The study was conducted in a laboratory experiment by testing inhibitory concentration gambir catechin extract, through Kirby Bauer disk diffusion method on plates TYCSB for $1 \times 24$ hours. Test bacteria Streptococcus mutans isolated from saliva. The used suspension of bacteria was made according to the standard turbidity of Mc Farland 0.5 are each $1 \mathrm{ml}$ suspension containing $1.5 \times 108$ bacteria. The powder obtained from catechin gambir extract through freezing method. Results: Catechins concentrations of $20 \%$ produces the lowest inhibition, with an inhibitory diameter of $0,615 \mathrm{~cm}$. The largest inhibition produces by the concentration of catechins with $80 \%$ inhibition at $1,085 \mathrm{~cm}$ inhibitory diameter. Conclusion: The higher concentration of catechins, the greater inhibition produces. Conversely, the lower concentration of catechins will be lower inhibition produces. the resulting zone of inhibition will be smaller.
\end{abstract}

Keywords: Inhibitory concentrations, gambier (Uncaria gambir Roxb.), catechins, Streptococcus mutans

\section{INTRODUCTION}

Caries is the most common oral disease in the community and its still a problem today. Dental caries is a severe infection in dental hard tissue which consists of the enamel, dentine, and cementum caused by the activity of a microorganism. The main bacterium that causes dental caries is Streptococcus mutans, in addition, other microorganisms play a role in the process of caries formation. ${ }^{1,2,3}$

Streptococcus mutans have cariogenic nature because they produce extracellular enzymes glucosyltransferase (GTF) that could break sucrose into glucan and fructan. Glucan is used to produce energy during anaerobic glycolysis process. Lactic acid as the result of glycolysis process could demineralize email that develops caries. ${ }^{4}$ (Gani, 2006).

An effort to prevent caries is by applying the principle of minimal intervention. This principle is a noninvasive treatment in the absence of dental hard tissue removal, and conditioning healthy oral cavity environment by controlling the growth of bacteria that cause dental caries. ${ }^{5,6}$ (Mount and Ngo, 2000; Samaranayake, 2002).

Management to inhibit and suppress the growth activity of Streptococcus mutans that cause 
caries can be done mechanically or chemically. Chemical control can be done by inhibiting the growth of caries-causing bacteria, such as the use of mouthwash, toothpaste, and other oral cleansers. $^{7}$ (Pradewa, 2008). The ingredients used as the basis for making oral cleansers can be derived from traditional plants, because they are natural, more easily absorbed and digested, and have less side effects than modern or synthetic drugs. ${ }^{8,9}$ (Thalib and Asmawati, 2002; Purnamasari, 2010). One alternative plant that can be used is gambier (Uncaria gambir Roxb).

Gambier plants are used by ancestors as an additive in the chewing ingredients for healthy teeth and gums. The part of the cultivated plant is the sap of leaves and twigs. Gambier is a functional plant part of flavonoid compounds class. The main content of this compound is polyphenols. Studies show that dominant polyphenolic compounds are catechins. ${ }^{10}$ (Heyne, 1987 in Pambayun, 2007). Catechin content in gambier extract is 7-33\%. ${ }^{11}$ (Amos, 2004). The high content of polyphenols in gambier leaves indicates that gambier is alleged to have antibacterial activity. ${ }^{12}$ (Hermawan, 2009).

Gambier extract has a high inhibitory effect on gram-positive bacteria (Streptococcus mutans, Staphylococcus aureus, Bacillus subtilis) but does not show the significant inhibitory effect on all gram-negative test bacteria (Escherichia coli, Salmonella thypimurium, and Shigella flexneri).$^{10}$ (Pambayun, 2007). The study was to analyze the inhibitory concentration gambir catechin extract against Streptococcus mutans as the bacteria that play a role in the formation of dental caries.

\section{METHODS}

This research is an experimental laboratory study, that testing catechin inhibition power of gambier extract (Uncaria gambir Roxb) to Streptococcus mutans by using diffusion method for Kirby Bauer. This Final Project was conducted in April-August 2012 at the Microbiology Laboratory of Faculty of Dentistry, Padjadjaran University.

The population in this research is catechin extract gambier. The sample is a catechin powder extracted by gambir freezing method. The independent variable in this research is catechin extract gambier with the freezing method at different concentration. The dependent variable was Streptococcus mutans isolate. Control variables are culture medium, facultative anaerobic atmosphere, temperature and time of incubation, standard bacteria turbidity test.

The operational definition of this research are, antibacterial power is the ability of the material to inhibit the growth or kill bacteria in a certain concentration. The diffusion method for Kirby Bauer is a method for testing the antibacterial power of an ingredient against a particular bacterium. The results that can be seen on the TYCSB plate have clear boundary zone around the circle, indicating that the area is the Minimum Inhibitory Concentration (MIC). The resulting scale is a numerical scale. Catechin powder of gambier extract is a gambier catechin which has been extracted by using the freezing method. The freezing method is a method used to separate catechins with tannins based on their nature of dissolution and polarity.

Streptococcus mutans is the most dominant group of bacteria from all microflora in the mouth, gram-positive, non-motile, splitting in one direction, cauliflower-like facultative anaerobic colonies, irregular margin, a bright white color that is very clear with a diameter between 0.5 to $0.8 \mathrm{~cm}$, is firmly attached to the growth medium.

This research uses standard tools in microbiology laboratories such as petri dish, object glass, incubator, refrigerator, bunsen's burner, filter paper, Desiccator (Klein hood), dermatographia pencil, microscope, oese, pipette, scales, Erlenmeyer flask, test tube, test tube shelf, and gram staining material.

The medium used is Tryptone Yeast Cysteine Sucrose Bacitracin (TYCSB) as a selective medium for the isolation of Streptococcus mutans, while sucrose bullion is used as a culture medium for genetically Streptococcus mutans. The test material of this research is catechin powder extract of gambier and bacteria for the test used is Streptococcus isolation and mutans from saliva.

This research procedure consists of identification of Streptococcus mutans, as well as catechin inhibition test of gambir extract. The examination material was obtained from saliva, then planted on TYCSB medium and incubated in the anaerobic facultative atmosphere at $37^{\circ}$ C for 48-72 hours. Colonies that form like white cauliflower, borderless, shiny and firmly attached 
to the surface of the media. ${ }^{3}$ (Wan, 2002). The suspected colony prepared with Gram staining.

The results of examination under the microscope seen Gram-positive bacteria shaped coccus by forming a line formation like a chain. Then, the cultures are grown on bulbs containing sucrose, then incubated at $37^{\circ} \mathrm{C}$. for $48-72$ hours in an anaerobic faculty to obtain a high number of pure Streptococcus mutans isolates.

The inhibitory test can be determined using the diffusion method for Kirby Bauer. The process is carried out in the following way: First, prepare the $100 \%$ concentrated catechin gambier powder from $100 \%$ concentration, then dilute the series starting from the $80 \%$ catechin concentration is by using six pieces of sterile test tube numbered 1-6. Tube number 1 filled with 2 grams of catechin powder and $2.5 \mathrm{ml}$ of sucrose bullion, 2-6 tubes filled with sucrose bullion every $2 \mathrm{ml}$. Transfer $2 \mathrm{ml}$ of homogenous catechin solution from tube number 1 to tube number 2 with sterile pipette then shake until homogeneous, so that dilution is obtained two times, then $2 \mathrm{ml}$ of solution in tube number 2 is put into tube number 3 to get four times dilution. Dilution was also performed on the fourth test tube to obtain eight times dilution. Further dilution was performed on the fifth test tube to obtain 16 times dilution, in the sixth tube $2 \mathrm{ml}$ of bullion solution as Positive Control (PC) was applied.

The test was performed by diffusion method to Kirby Bauer. Suspension of Streptococcus mutans was prepared according to McFarland 0.5 and incubated turbidity for $1-2 \mathrm{~h}$ at $37^{\circ} \mathrm{C} .14$ (Cappucino, 2004). A total of $0.1 \mathrm{ml}$ of suspension is grown on TYCSB and flattened with sterile lid cotton. The next step, on culture TYCSB, six holes were made with a diameter of $10 \mathrm{~mm}$ using a sterile perforator tool. In the first hole, $80 \%$ catechin extract solution was poured in approximately $2 \mathrm{ml}$ or until it fills the hole according to the thickness of agar. In the second hole is filled with $40 \%$ catechin extract solution of the same amount, in the third hole filled with $20 \%$ catechin extract solution, the fourth hole was filled with $10 \%$ catechin extract solution, in the fifth hole, $5 \%$ catechin extract solution was poured.

Then, the sixth hole bullion solution was included as a Positive Control (PC). Then the plates were incubated facultatively anaerobically at $37^{\circ} \mathrm{C}$ for $1 \times 24$ hours. After $1 \times 24$ hours, TYCSB was observed. When the material tested has antibacterial inhibition of the bacteria, it will show there is no bacterial growth in the area around the hole. The results seen on the TYCSB plate, there is a bounded inhibitory zone around the circle, indicating that the area is the MIC. The area is a zone where there is no bacterial growth. The TYCSB plate used amounted to 20 plates, divided into ten samples, performed in 2 repetitions.

\section{RESULTS}

The results of the isolation of Streptococcus mutans on TYCSB showed colonies that were shaped like cauliflower, irregular margin, a very clear white color with a diameter between 0.5 $-0.8 \mathrm{~cm}$. Results of planting for 24-36 hours with $37{ }^{\circ} \mathrm{C}$ at selective TYCSB medium in anaerobic faculty showed colonies as shown in the figure 1 .

The Gram staining result performed on the colony microscopically showed the shape of Grampositive cocci bacteria with chain formation as shown in the figure 2 .

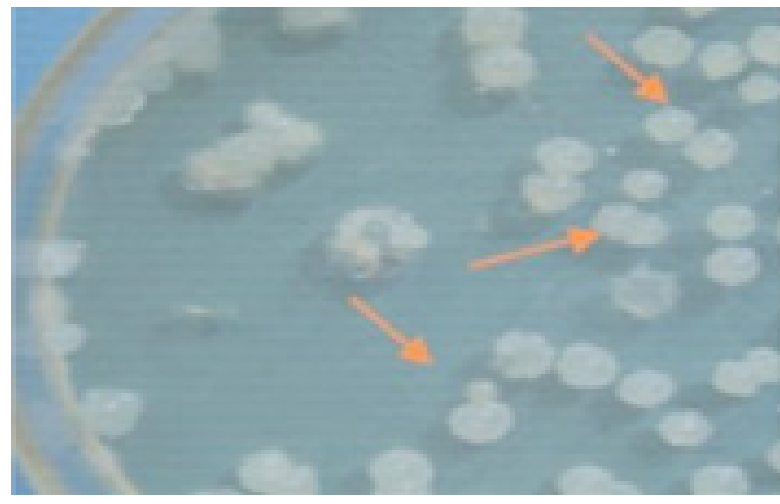

Figure 1. Colonies of Streptococcus mutans on the medium for TYCSB

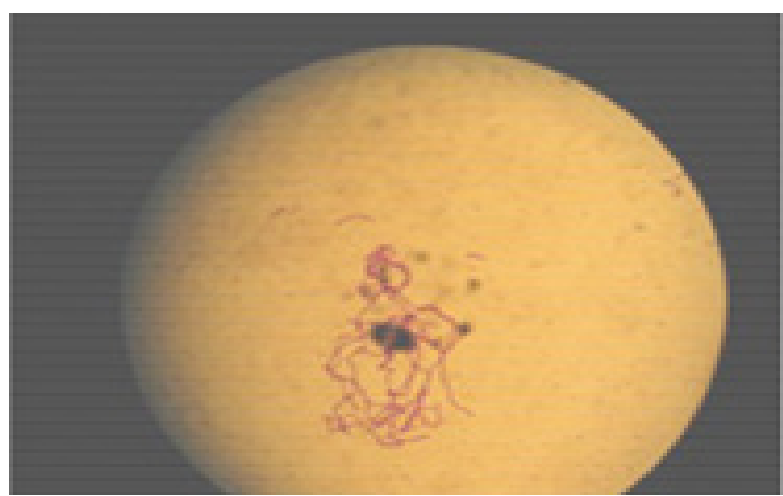

Figure 2. The result of staining GramTest 


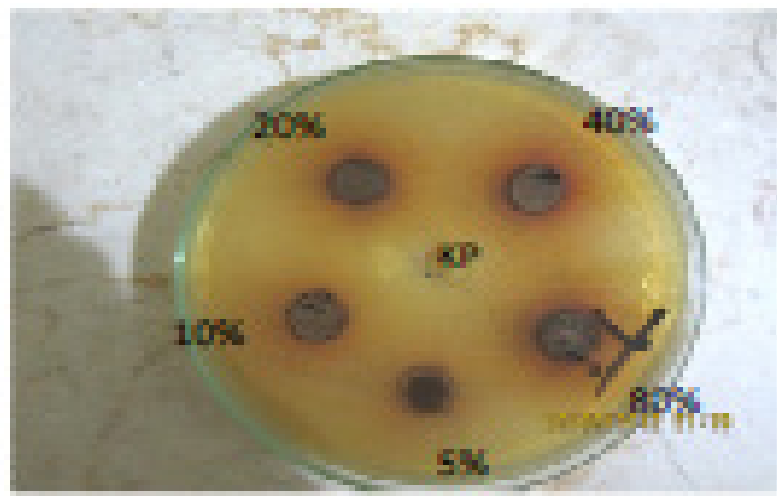

Figure 3. The results of catechin drawdown test of gambir at concentration $80 \%, 40 \%, 20 \%, 10 \%, 5 \%$ and $\mathrm{CP}$

The result of catechin gambier resistivity test against Streptococcus mutans shown in figure 3.

Based on the data retrieval table the average MIC of the research results can be calculated based on the calculation that the average inhibitory concentration X\% Plate (A-J) $=\Sigma \mathrm{n}:$ 10. According to research MOH RI (1989) a material can be said to have antibacterial characteristic if the MIC reach $6 \mathrm{~mm}$ or $0.6 \mathrm{~cm}$. The study result shows that catechins have inhibitory effect with 20\% initial concentration. Average 20\% catechin inhibitory concentration is $0.615 \mathrm{~cm}$, whereas catechins with $10 \%$ and $5 \%$ concentration produce only $0.455 \mathrm{~cm}$ and $0.275 \mathrm{~cm}$ inhibitory effect. In the research, the MIC has no significant effect / no inhibitory effect (because it is not suit the reference of $\mathrm{MOH} \mathrm{RI}, 1989)$. This result was obtained by calculating the average number of MIC of each plate in 2 repetitions. The average MIC of each plate is summed and divided by the number of plates. The number of samples in this study amounted to 10 samples. So the calculation is as follows, the average concentration of sample A was summed with the average MIC of samples $B$, $C, D, E, F, G, H, I$ and $J$. The divisor then divides the result of the total concentration is 10 . Based on the data obtained in the table, it can be seen that the smallest antibacterial catechins contained in catechin concentration of $20 \%$ with $0.615 \mathrm{~cm}$ zone of inhibition. The catechin concentration is $40 \%$, resulting in $0.85 \mathrm{~cm}$ zone of inhibition. Catechins that have the greatest inhibitory effect are at $80 \%$ concentration with a drag of $1.085 \mathrm{~cm}$. The greater the concentration of catechins, the greater the inhibitory effect is produced, and vice versa the less catechin concentration will be the smaller the inhibitory effect.

\section{DISCUSSION}

Gambir (Uncaria gambir Roxb) is a plant belonging to the flavonoid group, whose main content is polyphenols. Polyphenol compounds alter the properties of bacterial cell proteins. ${ }^{15}$ (Jenie, 2007). Polyphenols containing active compounds include catechins, which consist of epigallocatechin (EGC), epicatechin gallate $(E C G)$, epicatechin $(E C)$, epigallocatechin gallate (EGCG), catechin (C) and gallocatechin error (GCG).$^{15}$ (Ebadi, 2007). EGCG is believed to have the antibacterial effectiveness that binding peptidoglycan cell wall bacteria that can damage bacterial cell walls. EGCG and ECG can inhibit the action of glucosyltransferase enzyme from Streptococcus mutans. Mechanism of catechin work in inhibiting the growth of Streptococcus mutans through two ways that are as antibacterial in preventing dental plaque formation and inhibit glycosylation process. The ability of catechins as antibacterials is by denaturing proteins in bacterial cells. Catechins which are toxic compounds result in disruption of the threedimensional protein structure of bacterial cell it becomes open and random without damaging its covalent frame structure. That cause bacterial cell protein denatured, resulting in biological activity disruption which causes the protein unable to perform its function properly. Changes in the structure of proteins in bacterial cell wall will increase cells permeability so that cell growth will be inhibited and then the cell becomes damaged. ${ }^{17,18}$ (Hasim, 2006; Agustin, 2008).

The ability of catechins in inhibiting the glycosylation process is as follows; catechins will work competitively with glucosyltransferase (GTFs) in reducing saccharides which are the basic ingredients of the glycosylation process, so that the formation of extracellular polysaccharides in bacteria is inhibited. Catechin activity in lowering glucose is much higher than the movement of GTFs in using glucose. ${ }^{19}$ (Murray et al., 2003).

The catechin contains radical gallol or pyrogallol which can inhibit the activity of Lactate Dehydrogenase (LDH) enzyme or bacterial fatty acid enzyme by binding with the catalyst. Catechin 
content, epigallocatechin galat, and epicatechin can inhibit Streptococcus mutans attachment to the tooth particles because these bacteria have receptors called glucan-binding proteins. Dextrose can provide a carbon source for plaque bacteria by lowering glucan. The bounded glucan is converted by dextranase to glucose again and used in the process of glycolysis, which produces energy and lactic acid. ${ }^{16}$ (Ebadi, 2007). Glucosyltransferase is required by bacteria to attach to a surface to form biofilms. If the bacteria cannot be attached to the pellicle, it can not create a large colony so that the dental plaque will be reduced. The inability of bacteria to attach can also kill the bacteria itself because bacteria will not obtain sucrose as their food source. That causes the catechin gambier to show a significant antibacterial effect on Streptococcus mutans. ${ }^{16}$ (Ebadi, 2007).

According to the results of research on the inhibition of herbs containing toothpaste, it shows that based on the influence of phenol compounds on bacterial growth, zones of inhibition result against Streptococcus mutans increases in size and the number of Streptococcus mutans bacteria is reduced. That is by the results obtained about the inhibitory concentration of catechins from the gambier extract on Streptococcus mutans. It can conclude that the catechin extract gambier is as antibacterial. ${ }^{20}$ (Pratiwi, 2008). Catechin used in this study is catechin which is extracted through freezing method. Extracted catechin powder using this freezing approach has several advantages. The advantage is that the powder is purer, because the separation and purification process uses water as a solvent and uses a special machine in the process of processing, so that the components contained in this gambier catechin do not react much with other chemicals that can affect chemical content in catechins. Also, this freezing method is more economical and efficient, because the processing does not take too long and the material is relatively cheap, making it more profitable in the production process. ${ }^{21}$

\section{CONCLUSION}

The higher the concentration of catechins at the time of testing, the greater the MIC. Conversely, the lower the concentration of catechins, the resulting zone of inhibition will be smaller.

\section{REFERENCES}

1. Lanander, ML; Loimaranta, V. 2000. Saliva \& dental caries. J Adv Dent. 14:40-7.Diterjemahkan oleh Rafiah Abyono. Jakarta: EGC. 295-314 pp.

2. Russel. 2000. General bacteriological aspects of mutans Streptococci. Rev of Literature. p.1-14.

3. Indrawati, R. 2003. Aktivitas dextranase sebagai upaya pencegahan karies gigi (The prevention of dental caries with dextranase activity). Maj. Ked. Gigi. (Dent. J). Edisi Khusus Temu Ilmiah Nasional III 6-9 Agustus. h. 513516.

4. Gani, B. A; Tanzil, A; Mangundjaja, S. 2006. Aspek Molekuler Sifat Virulensi Streptococcus mutans. IJD. 13(2):107-14

5. Mount, G. J. Ngo, H. 2000. Minimal Intervention: Anew Concept for operative dentistry. Quintessence Int.Vol 31 No 8 . 527-533.

6. Samaranayake, L. P. 2002. Diagnostic microbiology and laboratory methods.In Essential Microbiology for Dentistry.2th ed,. Churchill Livingston. p.45-48.

7. Pradewa, M. R. 2008. Formulasi Sediaan Obat Kumur Berbahan Dasar Gambir (Uncaria gambir Roxb). Fakultas Teknologi Pertanian : IPB. Bogor. [skripsi]. [Diakses tanggal 21 januari 2012].

8. Thalib, B; Asmawati. 2002. Efek Antibakterial Ekstrak Metanol Daun Wungu (Graphtophyllum Pictum (L.) Grift) Terhadap Bakteri Streptococcus mutans. Jurnal PDGI Th 52. Edisi Khusus. p. 50-52.

9. Purnamasari, D. A; Munadziroh, E; Yogiarto, R. M. 2010. Konsentrasi ekstrak biji kakao sebagai material alam dalam menghambat pertumbuhan Streptococcus mutans. Jurnal PDGI Vol.59, No.1 Januari 2010. h.14-18.

10. Pambayun, R; Gardjito, M; Sudarmadji, S; Kuswanto, K. R. 2007. Kandungan fenol dan sifat antibakteri dari berbagai jenis ekstrak produk gambir (Uncaria gambir Roxb). Majalah Farmasi Indonesia 18 (3). h.141-146.

11. Amos, I; Zainuddin, A; Triputranto, B; Rusmandana; Ngudiwaluyo. 2004. Teknologi Pasca Panen Gambir. BPPT Press. Jakarta. [Diakses 
tanggal 21 Januari 2012].

12. Hermawan. 2009. Tanaman Gambir, Mutiara Baru dari Sumatera Barat.http;//bisnisukm. com. [Diakses tanggal 21 Januari 2012].

13. Wan, A. K. L; W. K. Seow; L. J. Walsh; et al. 2002. Comparison of five selective media for the growth and enumeration of Streptococcus mutans. Aus. Dental J. 47, 1, 21-26.

14. Cappuccino, J; N, Sherman. 2004. Microbiology A Laboratory Manual ( $7^{\text {th }}$ Edition) Pp. 129. 544pp. Benjamin Cummings. Retrieved from http://www.amazon.com/Microbiology-Laboratory-Manual-7th- Edition/dp/080532836X.

15. Jenie, B. S; Andarwulan, N; Puspitasarti, N. L; Nuraida, L. 2007. Antimicrobial Activity of Piper betle Linn extract Towards Foodborne Pathogens and Food Spoilage Microorganisms. [cited 2007 December 13]. Available from: URL: http://www.agnet.org/library/ rh/2003004a/.pdfumbuhan Obat Indonesia. [Diakses tanggal 16 September 2012].

16. Ebadi, M. 2007. Pharmacodynamics basis of herbal medicine. Edisi ke-2. New York: Taylor and Francis Group.

17. Hasim, D. 2006. Sirih Sebagai Anti Bakteri.
Available from: URL: http://www.kompas. com/kompas-cetak/0309/24/iptek/578008. htm. [diakses tanggal 31 Januari 2011].

18. Agustin, D. W. 2008. Perbedaan Khasiat Antibakteri Bahan Irigasi antara Hidrogen Peroksida 3\% dan Infusum Daun Sirih 20\% terhadap Bakteri Mix. [cited 2008 August 06]. Available from: URL: http://journal.unair.ac.id/filerPDF/DENTJ-38-1-12.pdf [Diakses tanggal 16 September 2012].

19. Murray, R. K; Granner, D. K; Mayes, P. A; Rodwell, V. W. 2003. Biokimia Harper. Jakarta. EGC. p. 650.

20. Pratiwi, R. 2008. Perbedaan Daya Hambat terhadap Streptococcus mutans dari beberapa pasta Gigi yang Mengandung Herbal. Available from: URL:http://journal.unair.ac.id/filerPDF/DENTJ-38-2-05.pdfinar Nasional XXVI. [Diakses tangga 14 Desember 2011].

21. Indrayana. 2010. Buku Panduan Penggunaan Alat Pemurnian Catechin dari Gambir Asalan dengan Metoda Freezing. Nanotech Indonesia. Puspitek-Balai Inkubator Teknologi (BIT) BPPT : Tangerang. h.1-13. 